\title{
Emotional Substrates of White Racial Attitudes
}

\author{
Antoine J. Banks University of Maryland \\ Nicholas A. Valentino University of Michigan
}

\begin{abstract}
A steep decline in biologically based racial animus over the past four decades has not led to a softening of opposition to race-conscious policies such as affirmative action. One explanation for this is that a new racial belief system-referred to as symbolic racism or racial resentment-has replaced "old-fashioned racism." Another is that nonracial values such as ideology and a preference for small government now drive policy opinions. Our theory suggests that whereas disgust once accompanied ideas about "biologically inferior" groups, anger has become fused to conservative ideas about race in the contemporary period. As a result, anger now serves as the primary emotional trigger of whites' negative racial attitudes. We experimentally induce disgust, anger, or fear using an apolitical task and find anger is uniquely powerful at boosting opposition to racially redistributive policies among white racial conservatives. Nonracial attitudes such as ideology and small government preference are not activated by any of these negative emotions.
\end{abstract}

A steep decline over the past 40 years in the belief that blacks are biologically different than, and inferior to, whites (Schuman et al. 1997) has not been accompanied by an increase in support for public policies intended to promote equal opportunity, such as affirmative action. A collection of "new racism" theories_including symbolic racism (Sears and Kinder 1971), racial resentment (Kinder and Sanders 1996), and modern racism (McConahay and Hough 1976; referred to hereafter as SR)-acknowledges that whites' "oldfashioned racism" (OFR) has genuinely receded over time in both prevalence and influence. In its place, a new racial belief system has emerged, rooted in an organic synthesis of antiblack affect and the sense that blacks violate cherished American values such as individualism (Kinder and Sanders 1996; Sears and Henry 2003).

The politics-centered approach (Sniderman, Crosby, and Howell 2000), on the other hand, insists these new racism theories overestimate the role of racial animus. Instead, they argue, race-neutral values (RNV) regarding the proper size and role of government, political ideology, and individualism drive racial policy opinions. This criticism focuses on two related dimensions. First, Sniderman and his colleagues contest the claim that a fundamental change underlying the meaning of negative racial attitudes has taken place, and thus they question whether OFR and SR are conceptually distinct (see, for example, Sniderman and Tetlock 1986). Second, these authors argue that measures of SR are contaminated with nonracial values such as individualism or preference for small government. These nonracial values, not racism, explain contemporary opposition to racially redistributive policies (Sniderman, Crosby, and Howell 2000).

Studies testing these competing hypotheses remain inconclusive, because all three dimensions-OFR, SR, and RNV-are correlated with each other and with policy opinions. The debate, then, often reduces to subjective characterizations of the explained variance of each dimension. We hope to move this debate forward by theorizing about the emotional substrates of each dimension. If these attitudes are indeed unique antecedents of racial policy opinions, they might be linked to unique emotional reactions in the minds of average citizens. Therefore, we propose moving a step back to consider whether distinct

Antoine J. Banks is Assistant Professor of Government and Politics, University of Maryland, 3140 Tydings Hall, College Park, MD 20742 (abanks12@umd.edu). Nicholas A. Valentino is Associate Professor of Political Science, University of Michigan, 4244 ISR, 426 Thompson St., Ann Arbor, MI 48109 (nvalenti@umich.edu).

This research was supported by the Gerald R. Ford Dissertation grant to the first author and by the Mike Hogg Endowment for Community Affairs and the Annette Strauss Institute for Civic Participation while the second author was at the University of Texas at Austin. The authors thank Erin Byrd, Joanne Ibarra, Sanata Sy-Sahande, and Kerry Jones for excellent research assistance and Vincent Hutchings, Donald Kinder, Norbert Schwarz, and Eric Groenendyk for helpful feedback. Data needed to replicate the analyses presented in this article can be found at http://web.me.com/antoinebanks/Antoine_Banks/Research.html.

American Journal of Political Science, Vol. 56, No. 2, April 2012, Pp. 286-297

(C) 2012, Midwest Political Science Association

DOI: $10.1111 / \mathrm{j} .1540-5907.2011 .00561 . x$ 
emotional antecedents of these racial belief systems exist. If so, then the debate is not simply a matter of proper measurement and model specification.

Our results have important implications for the racial policy opinion debate. First, to foreshadow the findings, our article supports the notion that SR is indeed conceptually distinct from OFR: biologically based beliefs about racial differences are linked to the emotion of disgust, while contemporary racial animus is not. Instead, SR is rooted in blame appraisals and, consequently, anger. Second, fear is not found to be powerfully linked to any of the belief systems examined here: experiencing fear does not boost opposition to racial redistribution among those high in SR, OFR, or RNV. Finally, RNV such as a preference for limited government or the belief in individual achievement are not activated by any negative emotion and therefore are distinct from both SR and OFR.

\section{Emotions and the Evolution from Old to New Racism}

The intuition that negative racial beliefs are coincident with strong negative emotions is not new. Proponents of the OFR, SR, and RNV hypotheses all suggest negative emotions accompany, if not drive, these dimensions. A simple "valence" approach, conceptually grouping negative emotions together, is often employed. For example, Kinder and Sears (1981) posit "symbolic racism is rooted in ... early learned racial fears" and Sears later contends antiblack affect is "experienced subjectively as fear, avoidance, and a desire for distance, anger, distaste, disgust, contempt, apprehension, unease, or dislike" (1988, 70). The politics-centered approach also acknowledges that opinions about race are highly emotionally charged (Sniderman, Crosby, and Howell 2000), but does not focus on specific emotions. Fear is assumed to underlie the concept of ethnocentrism-a generalized negative attitude toward those unlike ourselves (Kam and Kinder 2007). Many scholars suggest campaign strategists actively employ negative emotions as a tool to race bait (Olbermann, 2010; Reeves 1997; Toner 2006). Jamieson argues campaigns via racialized ads "play to whispered fears, prejudices privately held but publicly denied" $(1992,84)$.

To date, however, there has been very little attention devoted to the causal role of emotions in any of these belief systems. We suspect the emotional substrates of these attitudes are both powerful and more specific than previously recognized. We posit that emotions become linked to racial predispositions as a result of the dominant emotional tenor of political debates in a given historical period. When the link between emotion and ideas about race is strong, experiencing the emotion can activate the belief and thus cause a shift in support for relevant policies.

So which emotions should be linked to the OFR, SR, and RNV belief systems? Appraisal theories of emotion posit that emotional reactions in a given situation depend on the particular explanations individuals use to make sense of events in their lives (Smith and Ellsworth 1985). Emotions spring from relationships between the individual and her environment that involve threat or opportunity (Lazarus 1991). Lazarus (1991) identifies two types of appraisals. Primary appraisals determine whether an encounter is congruent with one's goals. This appraisal triggers positive or negative affect and occurs immediately, even prior to conscious thought. A negative affective reaction occurs when an event interferes with our goals, while positive affect occurs when the event seems to bolster the chance of success. Once this initial appraisal occurs, a secondary appraisal determines the cause and nature of the harm/benefit. This secondary process refines negative affect into more specific emotions such as anger, fear, and disgust. ${ }^{1}$ It is on this secondary appraisal process that we focus our attention.

Appraisals of physical contamination are essential to experiencing disgust. Rozin and Fallon describe the disgust reaction as "revulsion at the prospect of (oral) incorporation of an offensive object. The offensive objects are contaminants; that is, if they even briefly contact an acceptable food, they tend to render the food unacceptable" (1987, 23). Lazarus reasons that disgust indicates "a strong desire to keep the substance away to preserve one's bodily integrity" (1991, 260). In other words, core disgust is a reaction to a specific type of threat, one that might poison or contaminate the body. Moreover, humans seem to experience disgust reactions not only from bodily contamination, but also from moral transgressions (Lazarus 1991).

According to appraisal theory, anger occurs when there is certainty about the source of a threat and blame is clearly established (Lazarus 1991; Lerner and Tiedens 2006). Further, the degree to which an individual feels she has control over the offending situation can enhance angry reactions (Smith and Ellsworth 1985). Finally, fear occurs when threats cannot be controlled or

\footnotetext{
${ }^{1}$ A growing literature indicates even these secondary processes may occur very soon after exposure to a stimulus, perhaps even before the mind is conscious of many details about the threat (Damasio 1994; Gray 1987). This is the intuition underlying Affective Intelligence Theory (Marcus, Neuman, and MacKuen 2000). We cannot pinpoint the precise timing of emotional experience with our data, so we remain agnostic on this point.
} 
when there is uncertainty about how to address them (Huddy et al. 2005; Smith and Ellsworth 1985). So how might these appraisals map onto specific racial belief systems?

A hallmark of the OFR belief system is the presumed biological inferiority of blacks (Kinder and Sanders 1996; Sears 1988). Stereotypes of blacks as subhuman were often explicit in the cultural dialogue of the Reconstruction era (Mendelberg 2001). Popular rhetoric suggested blacks were morally and biologically deficient, animallike, dirty, and unintelligent (Blake and Dennis 1943; Karlins, Coffman, and Walters 1969; Katz and Braly 1933). High rates of poverty, criminality, and illiteracy were seen as evidence that citizenship rights were inappropriate for blacks. Strict separation of the races was deemed essential for maintaining the physical and moral "purity" of the white race (Fredrickson 1971). In fact, Cuddy, Fiske, and Glick (2007) provide some preliminary evidence for the automatic linkage between group stereotypes and feelings of disgust. Therefore, we expect the small minority who continue to score highly on OFR to be moved by disgust.

Our reading of contemporary debates about race in America led us to suspect the SR belief system is linked more strongly to anger than disgust or fear. While the belief that blacks are innately inferior has declined, many whites still suspect blacks choose not to try as hard. ${ }^{2}$ Mendelberg (2001) and Valentino, Hutchings, and White (2002) suggest a similar transformation has occurred in political communication: racial appeals that once argued blacks are biologically inferior have been replaced by those involving blacks' motivation and work ethic. If blacks are considered equal in ability, this perceived lack of motivation leads to blame. According to appraisal theories of emotion, this attribution is essential for anger. In other words, new racism is situated in the belief that blacks are to blame for their own disadvantages (Kinder and Sanders 1996; Sears and Kinder 1971), and this is likely to trigger anger. Of course, the threat of resource redistribution from white to black communities may prompt fear among whites, as group position theory (Blumer 1958; Bobo and Hutchings 1996) and the power-threat hypothesis (Key 1949) suggest. If so, then fear may in fact be most powerfully linked to SR. However, we do not see contemporary discussions of race as infused with uncertainty or a lack of control: the appraisals most often linked to fear. As a result, fear should not boost opposition to racial policies

${ }^{2}$ Of course, the laziness stereotype may overlap both OFR and SR belief systems, since some might believe dispositional differences between blacks and whites are innate. Consistent with this is the Huddy and Feldman (2009) argument that SR is a mixture of internal and external attributions. among those high in any of these racial or nonracial belief systems.

If contemporary discussions about race are dominated by blame rhetoric, anger will become powerfully fused to the SR belief system. Subsequently, for those high in SR, the experience of anger may trigger negative thoughts about blacks that will subsequently boost opposition to racially redistributive policies. DeSteno and colleagues observe such an effect: subjects induced to feel angry rate arbitrary outgroups more negatively (DeSteno et al. 2004). Mackie, Devos, and Smith's (2000) work on intergroup emotions reveals similar results. Individuals who appraise their ingroup as strong and powerful react with anger (not fear or disgust) and endorse action against outgroups. Might a similar process cause anger to become linked to RNV, such as preference for small government, individualism, or nonracial ideological identities? The politics-centered approach suggests people oppose racial policies such as affirmative action not because the recipients are black, but because they require large and inefficient government bureaucracies, or they undermine individual initiative. Violating these values via government policy could generate anger if people believe blacks are intentionally demanding unfair treatment in comparison to other groups. For example, Sniderman, Crosby, and Howell (2000) find most whites (both liberals and conservatives) are angry or upset by the phrase "black leaders asking for affirmative action." If these nonracial values drive resistance to racially redistributive policies, anger should also powerfully prime RNV and boost opposition to affirmative action among those high on measures of that belief system. Such an outcome would leave us in an indeterminate position. We would still not know if SR and RNV are distinct, because they would not have distinct emotional triggers.

Once the linkage between an emotion and a group attitude has been established, the experience of that emotion may activate, or prime, the predisposition. Bower's (1981) state-dependent theory of memory posits that emotion is instrumental in learning and recall. Information learned in one emotional state is more easily recalled when subjects are returned to that state. If our speculations about the dominant emotional underpinnings of specific racial attitudes are correct, then distinct belief systems should be primed when the linked emotion is experienced. As a result, those who hold these beliefs strongly should increasingly oppose racially redistributive policies. Our primary hypothesis, therefore, is that the experience of anger, even when generated by a nonpolitical stimulus, will boost opposition to racial policies among those high in SR. If the politics-centered approach is correct, anger should also have this effect for those high 
in nonracial values such as preference for small government. Second, we expect disgust (but not other negative emotions) will lead whites high in OFR to oppose racially redistributive policies.

We test these expectations in two ways. First, we use an experiment to independently induce negative emotions using a nonpolitical task. This study provides a precise test of the causal mechanism we think is at work in activating particular belief systems during racial policy opinion formation. A second test utilizes the 1985 American National Election Study (ANES) pilot study that contained measures of a wide variety of emotions and racial attitudes. These results are consistent with the experimental findings and strengthen the external validity of our inferences.

\section{Study 1}

An experiment was run through Polimetrix/YouGov, an Internet survey company, from April 21 to April 30, 2008. Polimetrix/YouGov uses a matching technique to draw its adult sample. Respondents are matched to the national population on gender, age, race, education, party identification, and political interest. The total sample size was 243 whites. ${ }^{3}$ There was substantial variation on age ( $26 \%$ were $18-34 ; 38 \%$ were $35-54 ; 36 \%$ were 55 and over), gender ( $48 \%$ female), and education ( $43 \%$ high school degree or less; $30 \%$ some college; $18 \%$ college graduate). An oversample of the South (128 respondents) was included in order to increase variation in OFR, since this belief system is more prevalent in Southern states (Valentino and Sears 2005). ${ }^{4}$ As a result of the oversample, the sample was more likely than the nation to identify as Republican (49\%) and conservative (49\%). ${ }^{5}$ The random assignment of subjects to conditions was successful: there were no significant differences across cells of the design in the proportion of sociodemographic or partisan variables. As a result, any differences in the poststimulus dependent measures can be attributed to the manipulation and not to other factors.

The experiment was conducted in two waves. This is an important, though costly, design choice. Many similar

${ }^{3}$ Seven subjects were dropped from the analysis because they failed to follow instructions. None of the results change substantively if these respondents are included.

${ }^{4}$ We did find white Southerners to be more racially conservative than white Northerners.

${ }^{5}$ We do not employ weights, since our goal is to estimate the effect of the manipulation. Weights are randomly distributed across cells, and inferences are unchanged when they are used. studies measure the primed dimension in the posttest, because researchers fear the pretest measure may itself activate thoughts about the group, thus eliminating any experimental effects. However, tapping racial attitudes in the posttest carries a different risk: that the stimulus itself will lead to changes in the primed dimension. A preferable design is to measure the racial attitudes in a pretest far enough in advance that it is unlikely to remain salient by the time the individual is exposed to the stimulus in the second wave. ${ }^{6}$ As a result, we measured attitudes a week prior to exposure to our emotion induction task. The first wave consisted of racial and general attitudes measures, i.e., SR, OFR, and RNV (including ideology, individualism, and size of government). Seven days later, respondents participated in Wave 2, which consisted of the manipulation followed by measures of racial policy opinions.

\section{Experimental Manipulation}

The experimental manipulation utilized two induction techniques common in psychological studies of emotion (Bower 1981; Ekman 1993; Lerner and Keltner 2001; Valentino et al. 2008). Subjects were asked to recall and focus on events, people, or occurrences that led them to experience a given emotion while viewing an image of a person with a facial expression corresponding to that emotion. ${ }^{7}$ The combination of written and visual stimuli ensures respondents experience distinct negative emotions (i.e., anger, disgust, and fear). Facial expressions have been shown to trigger the same emotion in the viewer (Ekman 1993). Subjects were asked via the computer to respond to the following query: ${ }^{8}$

Here is a picture of someone who is (ANGRY/AFRAID/DISGUSTED). We would like you to describe in general things that make you feel like the person in the picture. It is okay if you

${ }^{6}$ If some respondents were turned off by the measures of racial attitudes in the pretest, they might opt out of the second wave. This could dampen effects. Fortunately, mortality was equivalent across cells of the design. There was a recontact success rate of $60 \%$, and there were no biases across conditions on variables such as partisanship, education, and gender.

${ }^{7}$ The facial images were of the same middle-aged white woman. The pictures, displayed in the appendix, are drawn from Ekman's archive of emotional expressions (Ekman and Friesen 1976).

${ }^{8}$ For the relaxed condition, there was no image. The text for this condition was exactly the same as for the other conditions except the emotional label was replaced with the word "relaxed." A full description is available in the online supplementary information. 
don't remember all the details, just be specific about what exactly it is that makes you (ANGRY/ AFRAID/DISGUSTED) and what it feels like to be (ANGRY/AFRAID/DISGUSTED). Please describe the events that make you feel the MOST (ANGRY/AFRAID/DISGUSTED), these experiences could have occurred in the past or will happen in the future. If you can, write your description so that someone reading it might even feel (ANGRY/AFRAID/DISGUSTED).

Our technique does not focus the respondent's attention on politics or race. It is, therefore, a precise test of the hypothesis that emotions themselves can activate specific group-based belief systems. Had we asked the respondent to focus on political objects that caused him or her to experience specific emotions, one concern would be that thoughts about those objects, not the emotions they cause, were responsible for the changes we observe in policy views. Response length to the emotional prompt was unrestricted, but subjects were told to take a few minutes to write down anything in general that made them feel the intended emotion. After the induction, subjects completed a posttest questionnaire that included a variety of policy-opinion measures.

\section{Results}

First, we conducted a manipulation check to determine if the induction procedure operated as expected. Openended responses to the induction task were double-coded by two trained graduate students unaware of the hypotheses. They identified the intensity of any negative emotions expressed in the responses (the scale ranged from 0 to 1 , $0=$ none, $.5=$ some, and $1=$ extreme) ${ }^{9}$ The results of the manipulation check are presented in Table 1. As expected, participants in the anger condition expressed significantly more intense anger than those in the control (relaxed) condition, but did not express more fear or disgust. Correspondingly, respondents in the fear condition expressed more fear, but not more anger or disgust relative to the control. Participants in the disgust condition expressed more disgust, but also slightly more anger than the control. Coders correctly identified the fear expression $88 \%$ of the time, and $100 \%$ correctly identified the anger and disgust expressions. These results indicate that the induction performed as intended. The slightly overlapping experience of anger and disgust is not surprising,

\footnotetext{
${ }^{9}$ The reliability of our coders was high: Cronbach's alpha for
} anger $=.85$, fear $=.93$, and disgust $=.87$.

\section{TABLE 1 Manipulation Check}

\begin{tabular}{lccc}
\hline & $\begin{array}{c}\text { Intensity } \\
\text { of Anger } \\
\text { Expressed }\end{array}$ & $\begin{array}{c}\text { Intensity } \\
\text { of Fear } \\
\text { Expressed }\end{array}$ & $\begin{array}{c}\text { Intensity } \\
\text { of Disgust } \\
\text { Expressed }\end{array}$ \\
\hline Anger Condition & $\mathbf{B}$ (s.e.) & B (s.e.) & B (s.e.) \\
\hline Fear Condition & $.51^{* * *}$ & .01 & .02 \\
Disgust Condition & $.04)$ & $(.03)$ & $(.04)$ \\
Constant & $(.04)$ & $.48^{* * *}$ & .00 \\
& $(.04)$ & $.03)$ & $(.04)$ \\
$\mathrm{N}$ & .01 & .01 & $.44^{* * * *}$ \\
\hline
\end{tabular}

${ }^{*} \mathrm{p} \leq .1 ;{ }^{* *} \mathrm{p} \leq .05 ;{ }^{* * *} \mathrm{p} \leq .001$ (all by two-tailed test). Entries are unstandardized OLS regression coefficients, and the standard errors are in parentheses.

given how often these emotions co-occur in real life. This result provides a more conservative test of our hypotheses about the distinctive links between each emotion and various attitude dimensions.

To measure SR, we used Kinder and Sanders's (1996) four-item ANES battery. ${ }^{10}$ We created a scale of racial policy opinions covering a broad spectrum of economic and symbolic remedies to eliminate racial inequalities by summing responses to five items. The items include support for affirmative action, busing, government assistance to blacks, Confederate flag displays, and official observance of the Martin Luther King Jr. Holiday. The items scale nicely (Cronbach's alpha $=.75$ ). The exact question wording is located in the online supplementary information.

We predict the experience of anger will significantly boost opposition to racial policies among those high in SR. If so, the interaction between the anger condition and SR in a regression should be positive. We regressed racial policy opinions on emotion dummies (Anger, Disgust, and Fear), $S R$, and the interaction between the two, controlling for Ideology, Education, Income, South, Political discussion, and Age. ${ }^{11}$ Column 1 of Table 2 shows evidence consistent with these predictions. The interaction between anger and SR is in the expected direction and is substantively large. Neither fear nor disgust significantly boosts SR's impact on racial policy opinions. Further-

${ }^{10}$ Full question wording is located in the supplementary information.

${ }^{11}$ Political discussion is a measure of political topics subjects mentioned in their open-ended responses to the emotion induction. Controls are described in the supplementary information. 
TABle 2 The Priming Effect of Emotion for Racial and Nonracial Attitudes

\begin{tabular}{|c|c|c|c|c|}
\hline & $\begin{array}{c}\text { Racial Policies } \\
\text { B (s.e.) }\end{array}$ & $\begin{array}{c}\text { Racial Policies } \\
\text { B (s.e.) }\end{array}$ & $\begin{array}{c}\text { Racial Policies } \\
\text { B (s.e.) }\end{array}$ & $\begin{array}{c}\text { Racial Policies } \\
\text { B (s.e.) }\end{array}$ \\
\hline Anger*Symbolic Racism & $\begin{array}{l}.32^{* *} \\
(.14)\end{array}$ & & & $\begin{array}{l}.29^{* *} \\
(.14)\end{array}$ \\
\hline Disgust*Symbolic Racism & $\begin{array}{c}.08 \\
(.13)\end{array}$ & & & $\begin{array}{l}.08 \\
(.14)\end{array}$ \\
\hline Fear* Symbolic Racism & $\begin{array}{l}.09 \\
(.12)\end{array}$ & & & $\begin{array}{c}.06 \\
(.13)\end{array}$ \\
\hline Anger* Old-Fashioned Racism & & $\begin{array}{l}.57^{* *} \\
(.27)\end{array}$ & & $\begin{array}{l}.38 \\
(.24)\end{array}$ \\
\hline Disgust* Old-Fashioned Racism & & $\begin{array}{l}.49^{* *} \\
(.24)\end{array}$ & & $\begin{array}{r}.40^{*} \\
(.21)\end{array}$ \\
\hline Fear* Old-Fashioned Racism & & $\begin{array}{l}.35 \\
(.31)\end{array}$ & & $\begin{array}{l}.17 \\
(.27)\end{array}$ \\
\hline Anger* Limited Government & & & $\begin{array}{r}-.09 \\
(.12)\end{array}$ & \\
\hline Disgust*Limited Government & & & $\begin{array}{c}.07 \\
(.15)\end{array}$ & \\
\hline Fear*Limited Government & & & $\begin{array}{l}.03 \\
(.12)\end{array}$ & \\
\hline Anger Condition & $\begin{array}{l}-.15 \\
(.10)\end{array}$ & $\begin{array}{c}.06 \\
(.05)\end{array}$ & $\begin{array}{l}.15^{*} \\
(.08)\end{array}$ & $\begin{array}{r}-.17 \\
(.10)\end{array}$ \\
\hline Disgust Condition & $\begin{array}{r}-.07 \\
(.10)\end{array}$ & $\begin{array}{r}-.04 \\
(.05)\end{array}$ & $\begin{array}{r}-.03 \\
(.09)\end{array}$ & $\begin{array}{r}-.10 \\
(.10)\end{array}$ \\
\hline Fear Condition & $\begin{array}{r}-.04 \\
(.09)\end{array}$ & $\begin{array}{l}.00 \\
(.05)\end{array}$ & $\begin{array}{r}-.01 \\
(.08)\end{array}$ & $\begin{array}{r}-.03 \\
(.09)\end{array}$ \\
\hline Symbolic Racism & $\begin{array}{l}.37^{* * *} \\
(.09)\end{array}$ & & & $\begin{array}{l}.35^{* * *} \\
(.10)\end{array}$ \\
\hline Old-Fashioned Racism & & $\begin{array}{r}-.03 \\
(.16)\end{array}$ & & $\begin{array}{r}-.03 \\
(.14)\end{array}$ \\
\hline Limited Government & & & $\begin{array}{l}.23^{* *} \\
(.10)\end{array}$ & \\
\hline Ideology & $\begin{array}{l}.17^{* * *} \\
(.05)\end{array}$ & $\begin{array}{l}.31^{* * *} \\
(.05)\end{array}$ & $\begin{array}{l}.19^{* *} \\
(.08)\end{array}$ & $\begin{array}{l}.14^{* *} \\
(.05)\end{array}$ \\
\hline Education & $\begin{array}{r}-.05 \\
(.05)\end{array}$ & $\begin{array}{c}-.15^{* *} \\
(.06)\end{array}$ & $\begin{array}{c}-.13^{* *} \\
(.06)\end{array}$ & $\begin{array}{l}-.08 \\
(.05)\end{array}$ \\
\hline Income & $\begin{array}{l}-.07 \\
(.05)\end{array}$ & $\begin{array}{l}.03 \\
(.06)\end{array}$ & $\begin{array}{l}-.06 \\
(.06)\end{array}$ & $\begin{array}{l}-.03 \\
(.06)\end{array}$ \\
\hline Age & $\begin{array}{l}.002^{* *} \\
(.001)\end{array}$ & $\begin{array}{c}.001 \\
(.001)\end{array}$ & $\begin{array}{l}.002^{*} \\
(.001)\end{array}$ & $\begin{array}{c}.002^{* *} \\
(.001)\end{array}$ \\
\hline South & $\begin{array}{c}.03 \\
(.03)\end{array}$ & $\begin{array}{l}.07^{* *} \\
(.03)\end{array}$ & $\begin{array}{l}.06^{* *} \\
(.03)\end{array}$ & $\begin{array}{c}.03 \\
(.03)\end{array}$ \\
\hline Political Discussion & $\begin{array}{r}-.02 \\
(.15)\end{array}$ & $\begin{array}{c}-.10 \\
(.17)\end{array}$ & $\begin{array}{c}-.01 \\
(.17)\end{array}$ & $\begin{array}{r}-.03 \\
(.15)\end{array}$ \\
\hline Constant & $\begin{array}{l}.19^{* *} \\
(.08)\end{array}$ & $\begin{array}{l}.38^{* * * *} \\
(.07)\end{array}$ & $\begin{array}{l}.34^{* * * *} \\
(.08)\end{array}$ & $\begin{array}{l}.24^{* *} \\
(.09)\end{array}$ \\
\hline $\mathbf{N}$ & 181 & 172 & 184 & 163 \\
\hline
\end{tabular}

${ }^{*} \mathrm{p} \leq .1 ;{ }^{* *} \mathrm{p} \leq .05 ;{ }^{* * *} \mathrm{p} \leq .001$ (all by two-tailed test). Entries are unstandardized OLS regression coefficients, and the standard errors are in parentheses. Variables are coded $0-1$, where higher values indicate more opposition to racial policies. 


\section{FIGURE 1 Marginal Effect of Each Emotion on Policy Opinion as Symbolic Racism Changes}
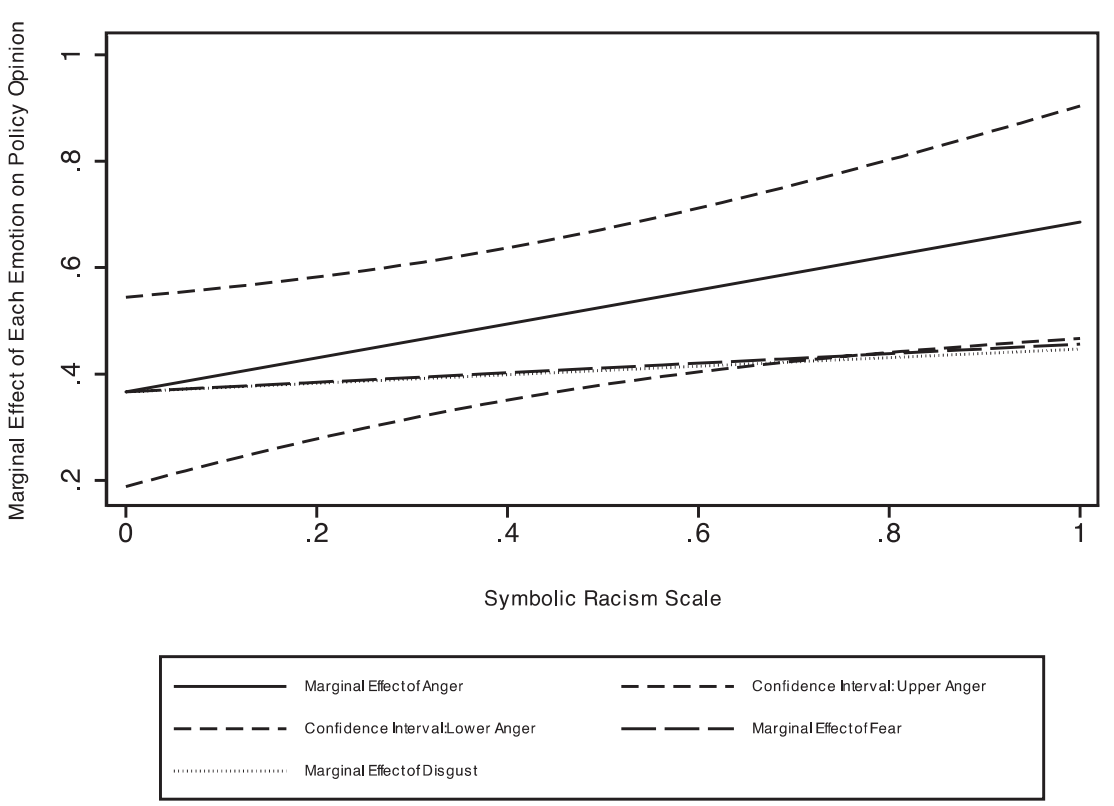

more, the priming effect for anger is statistically larger than that for either disgust or fear. ${ }^{12}$

Figure 1 illustrates the marginal effect of each emotion on racial policy opinions across levels of SR. The figure displays a $95 \%$ confidence interval, in short dashes, around the marginal effect of anger in the solid line. As we predict, as SR increases, anger increasingly boosts opposition to racial policies such as affirmative action. The marginal effect of fear, in long dashes, and disgust, in dots, is flat across levels of SR. At high levels of SR, anger produces significantly higher levels of opposition to racial policies than do the other emotions.

We also expected disgust to boost opposition to racial policies among those high in OFR. We measured OFR with a scale based on three items: (1) "On average blacks have worse jobs, income, and housing than white people. Do you think these differences are because most blacks have less in-born ability to learn?" (2) "Blacks come from a less able race and this explains why blacks are not as well off as whites in America," and (3) "How strongly would you object if a member of your family had a close relationship with a black person?" Column 2 of Table 2 displays a significant interaction between disgust and OFR on the racial policy index. Contrary to our expec-

\footnotetext{
${ }^{12}$ The difference $(\mathrm{F}, 1,168,2.62)$ is significant at the .1 level between anger*SR and fear*SR (two-tailed test). For anger*SR and disgust*SR, the difference $(\mathrm{F}, 1,168,2.58)$ is significant at the .11 level (two-tailed test).
}

tation, the impact of OFR on racial policy opinions was also significantly higher for those in the anger condition compared to those in the control group. In fact, the interaction between OFR and anger was slightly, though not significantly, stronger than that for OFR and disgust. Therefore, anger and disgust both seem to trigger OFR. Figure 2 displays these interactions visually and shows that the effects of anger and disgust are larger than that of fear, but these differences are not as large or statistically distinct. However, as OFR increases, both anger and disgust boost opposition to racial policies. At very high levels of OFR, both anger and disgust boost opposition significantly more than that in the (relaxed) control group.

In column 3 of Table 2, we examine the emotional underpinnings of an RNV, preference for limited government. If this value represents the primary driver of racial policy opinions, anger should also move opinions among those high on this dimension. The results in column 3 provide no support for this expectation. None of the interactions are substantively large or statistically significant on racial policy opinions. We replicated these analyses for two other race-neutral dimensions: nonracial liberal-conservative ideology and individualism. ${ }^{13} \mathrm{We}$ again found no significant interactions.

\footnotetext{
${ }^{13}$ Results for the interaction between emotions and ideology and individualism are available from the authors upon request.
} 


\section{FIgURE 2 Marginal Effect of Each Emotion on Policy Opinion as Old-Fashioned Racism Changes}
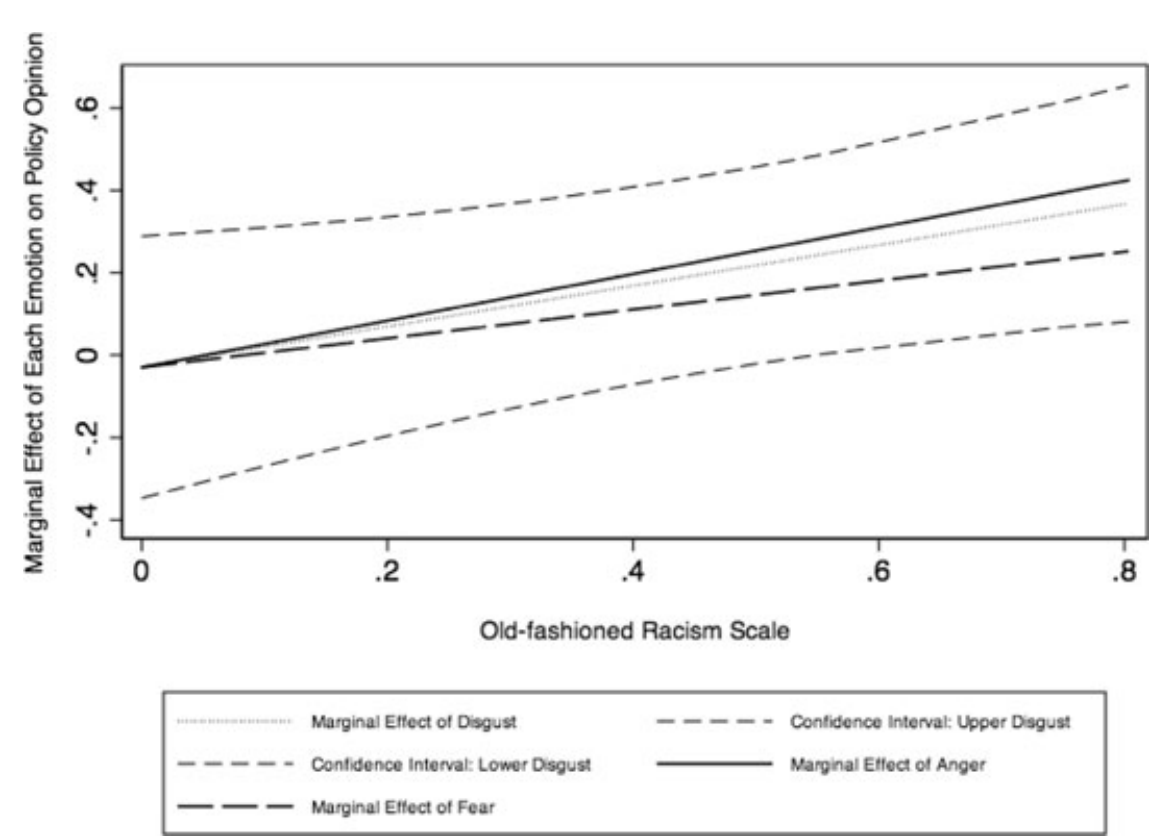

To further assess distinctions between SR and OFR, we ran an omnibus model including both sets of interactions described above. Researchers have found SR and OFR both to be driven by internal attributions (Huddy and Feldman 2009). As a result, we estimated the interaction of each emotion with SR and OFR simultaneously. Column 4 shows that SR still interacts only with anger while disgust now interacts significantly only with OFR. ${ }^{14}$ In other words, anger significantly moved opinions among those high in SR, while disgust moved those high in OFR. ${ }^{15}$

In summary, the results from Study 1 show that anger activates SR, while disgust primes OFR. Experiencing anger, independent of thoughts about race or politics, powerfully boosted the impact of SR on policy opinions. Disgust primed OFR, as we had originally predicted, but anger also activated this belief system as well. Fear did not activate racial thinking of any kind.

\footnotetext{
${ }^{14}$ In another model we included SR, OFR, and RNV (limited government) and interacted each attitude with anger, fear, and disgust. Results were nearly identical to those reported here.

${ }^{15} \mathrm{We}$ also examined these effects by region. The interaction between anger and racial resentment was strongest in the North $(.42, \mathrm{p} \leq$ $.05)$. The interaction between disgust and OFR was strongest in the South $(.80, \mathrm{p} \leq .05)$. This finding suggests SR is more powerfully linked to anger in the North while it is linked more strongly to disgust among Southerners.
}

While the results of Study 1 are supportive of many of our expectations, we still must be cautious in generalizing these effects to the national population. The main threat to external validity in the experiment is the realism of our manipulation: we directly induced emotions in order to maximize the distinctiveness of our respondents' reactions. Therefore, we now turn to a survey-based test. We utilize the 1985 ANES pilot study to test whether a significant relationship between particular emotions and predispositions (racial attitudes and race-neutral principle) can be produced in a nationally representative sample tapping emotional reactions toward several political attitude objects. This survey is useful because it contains emotion measures for disgust, anger, and fear as well as racial attitude measures (SR and OFR). For Study 2 we have two predictions. Anger, but not fear, toward several political objects is significantly correlated with SR. Disgust toward several political objects is significantly correlated with OFR.

\section{Study 2}

Here, we examine multivariate correlations between specific emotions and the three belief systems examined above: SR, OFR, and RNV. If our hypotheses are correct, correlations should be larger between anger and SR 
than with OFR or RNV. We also expect disgust to correlate most strongly with OFR, not SR or RNV. The 1985 ANES pilot study is a subsample of 429 participants from the 1984 ANES, a probability sample of Americans of voting age containing 392 whites. The study contained various questions about emotional reactions to affirmative action and race relations as well as to both the Democratic and Republican presidential candidates Reagan and Mondale. ${ }^{16}$ These measures are much different from the induction used in Study 1. We constructed scales of emotional states out of all the available emotion items across a wide range of targets in order to make the most conservative test possible: mean levels of anger across a variety of topics should be more correlated with SR than mean levels of other emotions. On the other hand, we expect disgust (across this range of targets) should be more closely linked to OFR, and fear should be linked to neither. Finally, preference for limited government should not be strongly correlated with any of these emotions. Note that if these measures merely tap partisan affect, they should cancel each other out when we combine evaluations of opposing parties. The strength of this test comes from taking the average emotional reaction to all targets, not simply emotional reactions to an individual's preferred candidate or party.

In column 1 of Table 3 , our expectation finds support. Whites' Anger is significantly linked to $S R$, controlling for Fear, Disgust, Ideology, Party Identification, Southern residence, Education, Age, and Gender. The link between anger and SR is larger and statistically distinguishable from that of fear (F, 1, 255, 3.12, p <.10 by a two-tailed test) and disgust (F, 1, 255, 4.08, $\mathrm{p}<.05)$. Neither disgust nor fear is significantly linked to SR. Contrary to our previous finding, however, column 2 displays no significant link between disgust and OFR. Finally, consistent with our expectation, column 3 shows that preference for Limited government is not correlated with anger, disgust, or fear.

These results parallel several of our experimental findings: anger, but not fear or disgust, is uniquely correlated with SR. Preference for limited government is unrelated to any of these emotional dimensions, suggesting that perhaps the link between anger and contemporary racial animus is particularly powerful. On the other hand, contrary to our expectation, we found no correlation between disgust and OFR.

\footnotetext{
${ }^{16}$ Items asked how "preferential treatment to blacks," "changes in race relations," and "presidential candidate Mondale/Reagan" make the respondent feel. Exact question wording is located in the supplementary information.
}

TABLE 3 Multivariate Relationship between Emotion and Racial and Nonracial Attitudes

\begin{tabular}{|c|c|c|c|}
\hline & $\begin{array}{c}\text { Symbolic } \\
\text { Racism }\end{array}$ & $\begin{array}{l}\text { Old-Fashioned } \\
\text { Racism }\end{array}$ & $\begin{array}{c}\text { Limited } \\
\text { Governmen }\end{array}$ \\
\hline & B (s.e.) & B (s.e.) & B (s.e.) \\
\hline Anger & $\begin{array}{l}.22^{* * *} \\
(.07)\end{array}$ & $\begin{array}{c}.06 \\
(.07)\end{array}$ & $\begin{array}{c}.09 \\
(.06)\end{array}$ \\
\hline Fear & $\begin{array}{l}.04 \\
(.07)\end{array}$ & $\begin{array}{r}-.01 \\
(.08)\end{array}$ & $\begin{array}{l}.02 \\
(.07)\end{array}$ \\
\hline Disgust & $\begin{array}{c}-.01 \\
(.06)\end{array}$ & $\begin{array}{l}.00 \\
(.07)\end{array}$ & $\begin{array}{l}.01 \\
(.06)\end{array}$ \\
\hline Education & $\begin{array}{c}-.08 \\
(.06)\end{array}$ & $\begin{array}{l}-.25^{* * *} \\
(.06)\end{array}$ & $\begin{array}{l}.10^{* *} \\
(.05)\end{array}$ \\
\hline Ideology & $\begin{array}{l}.02 \\
(.05)\end{array}$ & $\begin{array}{l}.06 \\
(.06)\end{array}$ & $\begin{array}{l}.14^{* * *} \\
(.05)\end{array}$ \\
\hline $\begin{array}{l}\text { Party Identi- } \\
\text { fication }\end{array}$ & $\begin{array}{l}.10^{* *} \\
(.05)\end{array}$ & $\begin{array}{r}-.02 \\
(.05)\end{array}$ & $\begin{array}{c}.08^{*} \\
(.04)\end{array}$ \\
\hline Gender & $\begin{array}{l}.05 \\
(.03)\end{array}$ & $\begin{array}{c}.02 \\
(.03)\end{array}$ & $\begin{array}{l}-.01 \\
(.03)\end{array}$ \\
\hline Age & $\begin{array}{l}.000 \\
(.001)\end{array}$ & $\begin{array}{l}.004^{* * *} \\
(.001)\end{array}$ & $\begin{array}{l}.002^{* *} \\
(.001)\end{array}$ \\
\hline South & $\begin{array}{l}-.01 \\
(.03)\end{array}$ & $\begin{array}{l}.08^{* *} \\
(.04)\end{array}$ & $\begin{array}{l}.03 \\
(.03)\end{array}$ \\
\hline Constant & $\begin{array}{l}.41^{* * *} \\
(.06)\end{array}$ & $\begin{array}{l}.19^{* *} \\
(.06)\end{array}$ & $\begin{array}{l}.20^{* * *} \\
(.06)\end{array}$ \\
\hline $\mathbf{N}$ & 264 & 275 & 258 \\
\hline
\end{tabular}

${ }^{*} \mathrm{p} \leq .1{ }^{* *} \mathrm{p} \leq .05 ;{ }^{* * *} \mathrm{p} \leq .001$ (all by two-tailed test). Entries are unstandardized OLS regression coefficients, and the standard errors are in parentheses. Source: 1985 ANES pilot study.

\section{Discussion}

How can we explain the contradiction apparent in a belief in the equality of the races paired with opposition to policies designed to bring it about? Survey data have long returned a contested answer: people are motivated either by racial bias or by principled views of how government works best. Much of the debate has focused on measurement difficulties: what do contemporary measures of racial animus such as SR really capture?

Most theories of racial policy opinion formation assume negative emotions are a critical component of opposition to racial policies such as affirmative action, but the emotional driver is rarely examined. Some have speculated whites feel a blend of negative emotions toward blacks (Kinder and Sanders 1996; Sears 1988). Our theory suggests specific emotional substrates activate 
different racial belief systems. We predicted that contemporary animus, as indicated by the SR scale, would be triggered primarily by anger, while OFR would be activated by disgust.

Our results show that SR is a distinct belief system, undergirded primarily by anger rather than disgust or fear. However, in Study 1 we found both disgust and anger triggered opposition to racial policies among those high in OFR. Given our interpretations of the kinds of attributions that might have dominated whites' thoughts about race when belief in biological differences was dominant, this is puzzling. One explanation, of course, is that our interpretations about appraisals taking place among people high in OFR are incorrect. Such whites may in fact experience anger in situations where they perceive an inferior group to be threatening their resources. Another possibility is that anger appraisals have found their way into the OFR belief system only recently. If so, we would expect both anger and disgust to boost opposition to racial redistribution among those high in OFR. While those high in racism may have once experienced disgust at the thought of racial intermixing, for example, they may now feel a mix of anger and disgust about the "demands" made by blacks embodied by policies such as affirmative action.

None of the negative emotions we explored boost opposition to racial policies for those high on RNV such as a preference for limited government. We suspect the reason is that abstract nonracial principles are simply not as emotionally charged as are ideas about groups, and thus they are not primed by the experience of any particular emotion. It is important to note, however, that the impact of RNV on policy opinion is significant regardless of the emotion experienced. This suggests racial and nonracial predispositions are distinct, both conceptually and in their effect on racial policy opinion. Symbolic racism is not, then, simply a substitute for nonracial values such as a preference for small government. Neither, however, does controlling for SR eliminate the effect of RNV in these models.

Contrary to much conventional wisdom and scholarly speculation, but as we suspected, fear did not prime OFR, SR, or RNV. Few whites experience a direct loss of rights or privileges at the hands of blacks, so they are unlikely to feel a lack of control over personal outcomes in situations where race is salient. Many who presume fear is central to whites' racial attitudes believe racial prejudice is caused by group competition (Blumer 1958; Key 1949). While we cannot conclusively rule out that fear is present in situations where group competition over concrete rights and resources is salient, we find no evidence that fear activates opposition to racial redistribution among those high in SR, OFR, or RNV. Further research is needed to determine whether fear might activate opposition among those who perceive high levels of group competition (Blumer 1958; Bobo and Hutchings 1996). The central finding bears repeating. When our subjects experienced anger-even when triggered by a completely nonpolitical, nonracial induction task-those high in SR came to oppose affirmative action and other racial policies. The survey results parallel this finding: the association between anger and SR was as large and significant as expected. On the other hand, there was no significant association between disgust and OFR in the survey evidence as we had found in the experiment. While this inconsistency casts doubt on our claim about disgust as the sole emotional substrate of old-fashioned racism, the differences in measurement of OFR between the two studies may partly explain the discrepancy. Our measures of OFR in Study 1 seem to capture more precisely the appraisals that produce disgust: the belief that blacks have less in-born ability and the objection to a family member having a personal relationship with a black person.

Although with these data we are unable to identify when in the lifespan the linkage between specific emotions and specific racial belief systems develops, we suspect it is probably learned at a young age. It may depend at least in part on the repeated experience of specific emotions at the time thoughts about the group are occurring. This link between discrete emotions and specific racial belief systems, we believe, dates back to when these attitudes began to develop. So certain whites are socialized from an early age to attribute certain emotional responses to blacks. As a result of this early socialization process, specific emotions and racial attitudes become fused such that experiencing the emotion later in adulthood activates the racial belief.

Barack Obama's speech entitled "A More Perfect Union," in the Constitution Center in Philadelphia on March 18, 2008, sums up well our argument and evidence. In the speech, condemning Reverend Jeremiah Wright's comments about race, Obama stated, "The anger is real, it is powerful; and to simply wish it away; to condemn it without understanding its roots, only serves to widen the chasm of misunderstanding that exists between the races." We agree that neglecting the emotional underpinnings of contemporary racism can lead us to ignore the pervasive role that racism continues to play in modern society. Myrdal (1944) believed the solutions to the "Negro" problem were to educate whites and publicize the problem. While most whites believe racial discrimination has been eliminated, our findings mandate caution. Racial animus 
partly remains because the primary negative emotion underpinning white attitudes toward blacks—anger-is so common in everyday life. Public anger surrounding contemporary movements like the Tea Party may, therefore, stem in part from, and trigger, racial prejudice (Parker and Barreto 2011; Zernike 2010). We think solving the problem Myrdal laid out over seven decades ago remains a challenge in contemporary America because it will involve breaking the powerful linkage between anger and ideas about race.

\section{Appendix: Facial Expressions Used in Emotion Induction Task}

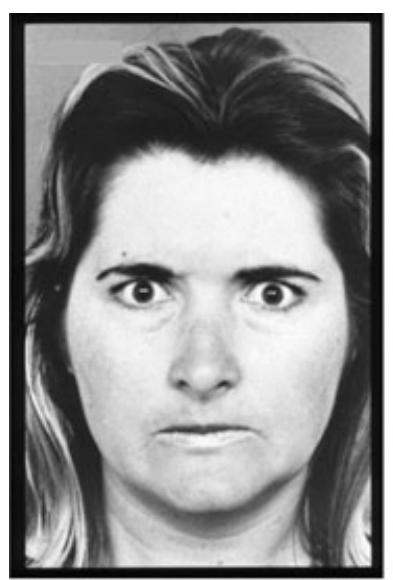

Anger Condition

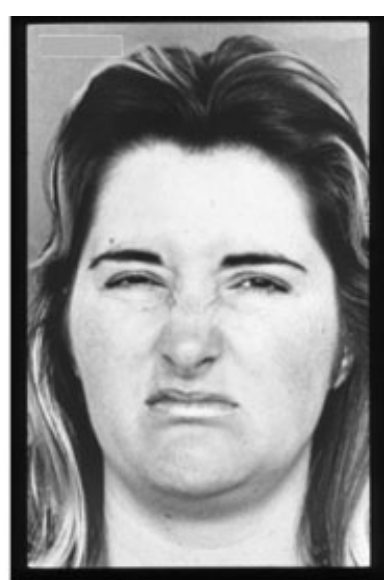

Disgust Condition

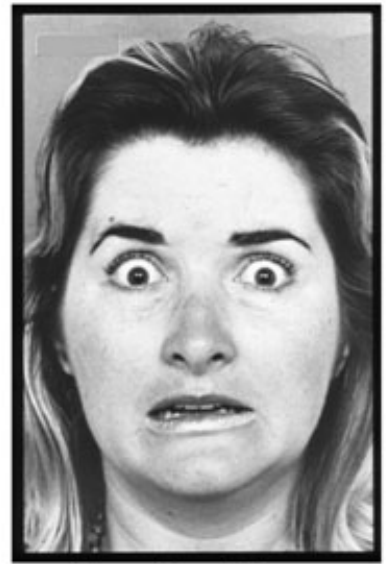

Fear Condition

\section{References}

Blake, Robert, and Wayne Dennis. 1943. "The Development of Stereotypes Concerning the Negro." Journal of Abnormal and Social Psychology 38 (October): 525-31.
Blumer, Herbert G. 1958. "Race Prejudice as a Sense of Group Position.” Pacific Sociological Review 1(1): 3-7.

Bobo, Lawrence D., and Vincent L. Hutchings. 1996. "Perceptions of Racial Group Competition: Extending Blumer's Theory of Group Position to a Multiracial Social Context." American Sociological Review 61(6): 951-72.

Bower, Gordon H. 1981. "Mood and Memory." American Psychologist 36(2): 129-48.

Cuddy, Amy J. C., Susan T. Fiske, and Peter Glick. 2007. “The BIAS Map: Behaviors from Intergroup Affect and Stereotypes." Journal of Personality and Social Psychology 92(4): 631-48.

Damasio, Antonio R. 1994. Descartes' Error: Emotion, Reason and the Human Brain. New York: Putnam and Sons.

DeSteno, David, Nilanjana Dasgupta, Monica Y. Bartlett, and Aida Cajdric. 2004. "Prejudice from Thin Air: The Effect of Emotion on Automatic Intergroup Attitudes.” Psychological Science 15(5): 319-24.

Ekman, Paul. 1993. "Facial Expression and Emotion.” American Psychologist 48(4): 384-92.

Ekman, Paul, and Wallace V. Friesen. 1976. Pictures of Facial Affect. Palo Alto, CA: Consulting Psychologists Press.

Fredrickson, George M. 1971. The Black Image in the White Mind: The Debate on Afro-American Character and Destiny, 1817-1914. New York: Harper and Row.

Gray, Jeffrey A. 1987. The Psychology of Fear and Stress. New York: Cambridge University Press.

Huddy, Leonie, and Stanley Feldman. 2009. "On Assessing the Political Effects of Racial Prejudice.” Annual Review of Political Science 12: 423-47.

Huddy, Leonie, Stanley Feldman, Charles Tabler, and Gallaya Lahav. 2005. "Threat, Anxiety, and Support of Antiterrorism Politics." American Journal of Political Science 49(3): 593-608.

Jamieson, Kathleen J. 1992. Dirty Politics: Deception, Distraction and Democracy. Oxford: Oxford University Press.

Kam, Cindy D., and Donald R. Kinder. 2007. "Terror and Ethnocentrism: Foundations of American Support for the War on Terrorism." Journal of Politics 69(2): 320-38.

Karlins, Marvin, Thomas L. Coffman, and Gary Walters. 1969. "On the Fading of Social Stereotypes: Studies in Three Generations of College Students." Journal of Personality and Social Psychology 13(1): 1-16.

Katz, Daniel, and Kenneth Braly. 1933. "Racial Stereotypes of One Hundred College Students." Journal of Abnormal and Social Psychology 28 (October): 280-90.

Key, V. O., Jr. 1949. Southern Politics in State and Nation. New York: Knopf.

Kinder, Donald R., and Lynn M. Sanders. 1996. Divided by Color: Racial Politics and Democratic Ideals. Chicago: University of Chicago Press.

Kinder, Donald R., and David O. Sears. 1981. "Prejudice and Politics: Symbolic Racism versus Racial Threats to the Good Life." Journal of Personality and Social Psychology 40(3): 414-31.

Lazarus, Richard S. 1991. Emotion and Adaptation. New York: Oxford University Press. 
Lerner, Jennifer S., and Dacher Keltner. 2001. "Fear, Anger and Risk.” Journal of Personality and Social Psychology 81(1): 146-59.

Lerner, Jennifer S., and Larissa Z. Tiedens. 2006. "Portrait of the Angry Decision Maker: How Appraisal Tendencies Shape Anger's Influence on Cognition." Journal of Behavioral Decision Making 19(2): 115-37.

Mackie, Diane M., Thierry Devos, and Eliot R. Smith. 2000. “Intergroup Emotions: Explaining Offensive Action Tendencies in an Intergroup Context." Journal of Personality and Social Psychology 79(4): 602-16.

Marcus, George E., W. Russell Neuman, and Michael MacKuen. 2000. Affective Intelligence and Political Judgment. Chicago: University of Chicago Press.

McConahay, John B., and Joseph C. Hough Jr. 1976. "Symbolic Racism." Journal of Social Issues 32(2): 23-45.

Mendelberg, Tali. 2001. The Race Card: Campaign Strategy, Implicit Messages, and the Norm of Equality. Princeton, NJ: Princeton University Press.

Myrdal, Gunnar. 1944. An American Dilemma: The Negro Problem and Modern Democracy. New York: Harper and Row.

Olbermann, Keith. 2010. "Beware Fear's Racist Temptation: Don't Blame Your Fear of the Future on Obama's Skin Color." MSNBC, February 15. http://www.msnbc.msn .com/id/35413401/.

Parker, Christopher S., and Matt A. Barreto. 2011. "Exploring the Causes and Consequences of Tea Party Support." University of Washington. Typescript.

Reeves, Keith. 1997. Voting Hopes or Fears? White Voter, Black Candidates and Racial Politics in America. Oxford: Oxford University Press.

Rozin, Paul, and April E. Fallon. 1987. "A Perspective on Disgust.” Psychological Review 94(1): 23-41.

Schuman, Howard, Charlotte Steeh, Lawrence Bobo, and Maria Krysan. 1997. Racial Attitudes in America: Trends and Interpretations. Rev. ed. Cambridge, MA: Harvard University Press.

Sears, David O. 1988. "Symbolic Racism." In Eliminating Racism: Profiles in Controversy, ed. Phyllis Katz and Dalmas Taylor. New York: Plenum Press, 53-84.

Sears, David O., and P. J. Henry. 2003. "The Origins of Symbolic Racism.” Journal of Personality and Social Psychology 85(2): 259-75.
Sears, David O., and Donald Kinder. 1971. Racial Tensions and Voting in Los Angeles. In Los Angeles: Viability and Prospects for Metropolitan Leadership, ed. W. Hirsch. New York: Praeger, 51-88.

Smith, Craig A., and Phoebe C. Ellsworth. 1985. "Patterns of Cognitive Appraisal in Emotion." Journal of Personality and Social Psychology 48(4): 813-38.

Sniderman, Paul M., G. C. Crosby, and W. G. Howell. 2000. "The Politics of Race." In Racialized Politics: The Debate about Racism in America, ed. David Sears, Jim Sidanius, and Lawrence Bobo. Chicago: University of Chicago Press, 263-79.

Sniderman, Paul M., and Philip E. Tetlock. 1986. "Reflections on American Racism." Journal of Social Issues 42(2): 173-87.

Toner, Robin. 2006. "Ad Seen as Playing to Racial Fears." New York Times on the Web, October 26. http://www .nytimes.com/2006/10/26/us/politics/26tennessee.html.

Valentino, Nicholas A., Vincent L. Hutchings, Antoine J. Banks, and Anne K. Davis. 2008. "Is a Worried Citizen a Good Citizen? Emotions, Political Information Seeking, and Learning via the Internet." Political Psychology 29(2): 247-73.

Valentino, Nicholas A., Vincent L. Hutchings, and Ismail K. White. 2002. "Cues That Matter: How Political Ads Prime Racial Attitudes during Campaigns." American Political Science Review 96(1): 75-90.

Valentino, Nicholas A., and David O. Sears. 2005. "Old Times There Are Not Forgotten: Race and Partisan Realignment in the Contemporary South." American Journal of Political Science 49(3): 672-88.

Zernike, Kate. 2010. Boiling Mad: Inside Tea Party America. New York: Times Books.

\section{Supporting Information}

Additional Supporting Information may be found in the online version of this article.

Please note: Wiley-Blackwell is not responsible for the content or functionality of any supporting materials supplied by the authors. Any queries (other than missing material) should be directed to the corresponding author for the article. 